\section{ECONOMICS}

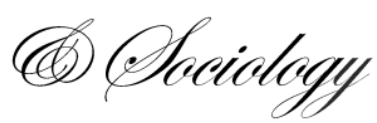

Sági, J., Vasa, L., \& Lentner, Cs. (2020). Innovative solutions in the development of households' financial awareness: A Hungarian example. Economics and Sociology, 13(3), 27-45. doi:10.14254/2071-789X.2020/13-3/2

\title{
INNOVATIVE SOLUTIONS IN THE DEVELOPMENT OF HOUSEHOLDS' FINANCIAL AWARENESS: A HUNGARIAN EXAMPLE
}

\author{
Judit Sági \\ Budapest Business School_- \\ University of Applied Sciences, \\ Budapest, Hungary \\ E-mail:sagi.judit@uni-bge.bu \\ ORCID 0000-0003-4197-3530

\section{László Vasa} \\ Széchenyi István University, \\ Györ, Hungary \\ E-mail:laszlo.vasa@ifat.bu \\ ORCID 0000-0002-3805-0244 \\ Correspondent Author

\section{Csaba Lentner} \\ National University of Public \\ Service, Budapest, Hungary \\ E-mail:Lentner.Csaba@uni- \\ nke.bu \\ ORCID 0000-0003-2241-782X
}

Received: February, 2020

1st Revision: May, 2020

Accepted: September, 2020

DOI: $10.14254 / 2071-$

789X.2020/13-3/2

JEL Classification: D14, D91, I25

\begin{abstract}
Financial crises put stress on the society of the country of our investigation, whose financial vulnerability is raising from high indebtedness, a history of defaulted loans, and an insufficient level of financial literacy. In this context, financial awareness has been recognised as a means for decreasing households' exposure to financial difficulties, bridging crisis periods with the substantial precautionary holding of liquid assets, and improving their well-being over longer periods of time. Raising financial awareness is a crucial policy aim, and has been investigated in this study as well. A questionnaire survey was completed by Hungarian university students across different majors, to assess the financial literacy level of the responders from their own perspective. In addition to this, we have investigated their e-banking habits. According to our findings, different student groups (clusters) have been identified by means of Ward analysis (where the significance of clusters were tested by ANOVA). Our results confirm that across all clusters the university students place their trust in non-governmental organisations and central bank foundations rather than those of the financial institutions in evolving financial literacy. This outcome of our study may provide an argument for designing policy incentives for raising financial awareness in an institutionalised way, relying on the role of the privately funded NGOs and on the central bank.
\end{abstract}

\footnotetext{
Keywords: financial literacy, non-governmental organisations, young adults, Hungary, questionnaire survey.
} 


\section{Introduction}

In the financial stability of a national economy, in addition to the macroeconomic provisions(the budget balance and the external balance), increasing significance has been always assigned to the financial balance of households, one of the primary income holders, based on employees' incomes from work and social benefits. The subprime crisis that started in the spring of 2007 on the Anglo-Saxon mortgage markets was primarily due to household overlending, and due to banks' normative behaviour in the lending market, it soon spread globally. As an inevitable concomitant, the amount of defaulted loans rocketed (Agarwal et al., 2014; Dahlstrom, 2014). Although the expansion of budget sectors and central banks solved the liquidity and capitalisation-related problems of commercial banks struggling with problematic loan portfolios, banks practising more prudent lending and households using credits more consciously are considered as longer-term stabilising factors (Lentner et al., 2015). In facilitating the latter, the beneficial impacts of improvement by the government and by civil society organisations, especially in the field of financial awareness, are indispensable. This study analyses the conditions in Hungary, as an entity that spent decades in a socialist-type planned economy regime. Market reforms in Hungary were launched at the end of the 1980s, adjusting ownership relations and institutional system in the country, and more specifically, its central and commercial banking system to the market standards of Europe. However, similar to other post-socialist countries that have already switched to market relations, to this very day Hungary has been afflicted by the consequences of the past and faces numerous difficulties in its social positions, including households' financial management, financial awareness, and quality of finance (Dobák \& Sági, 2005). As a result, social positions are more vulnerable than those of highly developed market economies, and consequently, would require a more pronounced involvement of the government and, especially, civil society organisations (Spolaore \& Wacziarg, 2013; Rikmann \& Keedus, 2012).

This study surveys the financial conduct and awareness among the university students between 18 and 31 y.o. (the "emerging" generation just before starting a family) in a breakdown by gender, educational profile, regional distribution and the regional development differences. Marcolin and Abraham (2006) suggested including the field of study when examining financial literacy among the university students, therefore, we have decided to extend our research to different majors. Our findings fill a literature gap because the survey on university students' financial literacy, broken down into economic, technical and other majors, is combined with their financial conduct in practice. Conclusions of our survey shed light on certain problems of the post-socialist territories. What lends special relevance to this study is the fact that despite three decades of successful transition to a market economy, the level of development and wages in the Central and Eastern European Region, including Hungary, remain approximately 75 per cent behind the average of the core Member States of the European Union and nearly 50 per cent behind the average pay rates in the United States of America (according to the Eurostat and the U.S. Bureau of Labor Statistics, estimated hourly labour costs). Still, households' consumer attitudes, especially their propensity to purchase and the extent of purchases, have been adjusted to developed market economies for several decades. Consequently, it had to be supplemented due to dependence on the credit facilities offered by the commercial banks active in the region, as well as the fact that both the disposable labour income and the welfare benefits aimed at closing gaps remain below the level of consumption. Furthermore, the propensity to purchase is considerably higher than that in Western Europe or in North America due to the slow increase in incomes, weak accumulation capacity and the consequent postponement of purchases. If, however, this is not accompanied by a responsible attitude in family finances, the banking sector in the region, and especially its society, may suffer considerable damage and 
even social conflicts (Falk et al., 2018). Amidst the ongoing pandemic situation, many households experience a sharp decline in their regular (wage) incomes, which, in the absence of a considerable amount of savings, may threaten their living conditions. In Hungary, in the 2nd quarter of 2020 GDP declined by $13.6 \%$ as compared to the corresponding period of the previous year, with a negative impact on the performance of most sectors of the economy. This drop is even worse than the 3rd quarter of 2008, when there was a 7.5 per cent fall (Hungarian Central Statistical Office data). Our hypothesis is that the activities undertaken by organisations established by the civil society, by commercial banking institutions or by central banks to improve financial literacy, which constitute the subject-matter of this analysis, are of pivotal significance in today's context.

The structure of the study is as follows. First, the significance of financial awareness is explained, from the economic policy perspective and in light of the OECD-INFE recommendations. Then, in the Data and Methods section, details about the survey questionnaire are presented (the survey has been conducted on a sample of university students, representing $86.2 \%$ of the total students' population in Hungary). The data analysis gives grounding for the clusters whose characteristics are described in the Results section. Following this, institutional solutions for improving financial literacy are discussed, along with the conclusions concerning the role of non-governmental and non-profit organisations. Finally, Summary completes the study.

\section{Literature review}

The economic policy actions taken to improve financial awareness are, in fact, reasonable responses to the increase in risks as a result of the complexity of the financial environment (Bateman et al., 2011, Dhandayuthapani \& Vinothkumar, 2020). In this context, this paper focuses on the policy mix elements that are the most suitable for supporting consumers' responsible financial decisions and for the prevention of their excessive indebtedness. The factors contributing to their modes of action include the extent of premeditation or impulsiveness in household saving and borrowing decisions, the likelihood of making the wrong decisions and the predictability of wrong decisions (Croy et al., 2010; Courchane \& Zorn, 2008). Financial literacy is improved within the framework of central banks' monetary policies and through commercial banks' lending practices, and its practical implementation falls within the scope of the corporate social responsibility of central banks and commercial banks. As a result of the crisis, increasingly responsible and conscious banking policies are gaining ground both in the central and commercial banking systems, enhancing their social sensitivity and, in the event of procedures vis-a-vis bank customers, increasing the responsibility assumed (Lentner et al., 2015). However, it is important that civil-society organisations, i.e. those independent of the banking sector, should have a major role in mitigating citizens' feeling that the efforts made for the improvement of financial literacy constitute a top-down or institutional pressure and thereby increase their acceptance by the population. However, in Hungary, a country that has taken a particular trajectory in economic and social development, civil society organisations, completely independent of public institutions and commercial banks, are still in their infancy.

The OECD International Network on Financial Education (OECD-INFE, 2016) regularly publishes data concerning the findings of its survey conducted once every three years in 30 countries. This serves to assess the financial literacy and financial inclusiveness of the respondent households with the use of a questionnaire. Based on the findings of the 2015 international survey, the OECD formulated a finance policy recommendation for a combination of the regulatory and consumer protection framework with financial education to improve 
households' financial resilience to financial shocks. Linking financial regulation with the consumer protection framework may prevent households from taking excessive amounts of loans and thus getting into a debt trap due to late repayments (Guerrieri \& Lorenzoni, 2017). Deterioration in households' financial position can frequently be fended off by simply choosing financial products that correspond to their actual income situation (Calcagno \& Monticone, 2015). Independent financial and investment consultancy services supported by the regulatory environment may help households in achieving their long-term goals even in the current environment of altering interest rates (OECD-INFE, 2018; Hansen 2012).

According to the definition published by OECD-INFE, financial literacy is 'a combination of awareness, knowledge, skill, attitude and behaviour necessary to make sound financial decisions and ultimately achieve individual financial wellbeing' (OECD-INFE, 2018, p. 4). This expression refers to a person's skills relating to finances and investments (Fernandes et al., 2014), as a form of personalised capabilities (Remund, 2010), and their behaviour reflects a person's financial awareness (Potrich et al., 2016). A survey of the level of financial literacy may set the direction for the elaboration and development of a system of financial education and consumer protection (Kempson, 2009) as well as recommendations on the development of financial competences via appropriate improvements of learning process (Berková \& Krpálek, 2017).

Society has three expectations of financial education: to hand down up-to-date information on financial investments and assets as well as banking and investment products; to shed light on fundamental financial correlations (such as the time value of money, and the advances of portfolio diversification etc.); and to provide a glimpse into the procedure of planning, implementing and evaluating financial decisions (Hogarth, 2006; Haynes-Bordas et al., 2008). It expected to accomplish the above to improve, or at least to prevent further deterioration in the standard of living and welfare for the individuals living in the given society (Mitchell \& Lusardi 2015; Atkinson \& Messy, 2012), with prospects for the elderly as well.

Financial literacy provides individuals with abilities to improve their financial wellbeing through their daily decisions (Quach, 2016). Within this scope, decisions relating to regular savings (Lusardi et al., 2010; Lusardi \& Tufano, 2015) may contribute to smoothing fluctuations in revenues and expenditures and improve the predictability of incomes and expenses (Galperti, 2017). If coupled with profitable investment decisions, household budgeting may contribute to increasing private assets (Ameriks et al., 2003), thus selfawareness may lead to wealth accumulation (Bazley et al., 2020). When a household plans the use of its financial savings, it sets expenditure targets, outlines alternative methods for achieving them, and takes account of limiting factors and the impacts of other conditions on the outcome (Lynch et al., 2010). In the course of planning their assets for the long term, households with high financial literacy consider the various alternative possibilities of investment, such as the purchase and holding of stock-exchange traded investment securities or pre-retirement savings (Van Rooij et al., 2011; Clark et al., 2006).

Policy issues related to the improvement of financial awareness may ask for the active role of non-governmental organisations (NGOs). The involvement of civil society organisations is based on a survey of the measurability of the (added) social value they create, which places financial literacy in a social context (Kato et al., 2018, Maas \& Liket, 2011, Maier et al., 2015). Arising from their function, civil society organisations can have a proactive role in expanding individual (in this case: student) skills, in converting the acquired knowledge into values, and in facilitating the birth of functional outcomes from theoretical knowledge (Robeyns, 2006). Also, they can moderate the hazards posed by risky financial decisions made as a result of insufficient financial literacy to the given individual's quality of life and, indirectly, to society (Sen, 2004, Walker, 2005 and Qizilbash, 2002). Last but not least, civil society organisations 
may transfer the values arising from corporate social responsibility to young adults in higher education (Rim et al., 2016), especially considering the fact that financial consciousness and setting long-term financial goals are less typical among young adults (Németh \& Zsótér, 2019).

Due to the late rise of the middle classes, which only started in the second half of the 19th century, and the forty years of a socialist-type planned economy, the presence of civil society organisations in Hungary - disregarding the NGO's facilitating conflict management (Stroschein, 2002) - is still less perceptible. Moreover, after the change of regime, the restrictive economic policy actions were taken during the transition to a market economy to the detriment of society (Lentner, 2020). In particular, the professional scepticism relating to the sustainability of the decade of consolidation after the crisis (Csaba, 2019), and the concerns about the sustainability of the operation of Hungarian enterprises, which are potential philanthropists, (Mihályi \& Szelényi, 2019) cast a shadow over the functionality and strengthening of the private sector and the civil society organisations developing from the latter. At the same time, it is a fact that the income positions of the national economy and households improved over the past decade (Matolcsy, 2016), which in turn creates reliable basis for wellbeing increase and overall socioeconomic prosperity of the state (Bilan et al., 2020). However, the country-specific features arising from relatively insufficient development have determined the frames for civil society organisations up to this date: in this framework, the non-profit organisations associated with the central bank and with commercial banks predominate, while there is a chronic deficit in foundations relying on private capital, and thus absolute philanthropy.

Based on our research, financial literacy can only be significantly shaped over the long term, if at all (Sági \& Lentner, 2019). Cooperation between the civil society organisations of various backgrounds is indispensable in the sustainable improvement of financial literacy (Kovács \& Terták, 2019). Financial training courses improve the population's financial skills in general, but this is not typically the case for lower-income social layers (Kaiser \& Menkhoff, 2017). Irrespective of social standing, borrowing and consumer habits are extremely difficult to influence, especially in light of the fact that they predominantly develop on the basis of patterns learnt in childhood (McCormick, 2009).

\section{Methodological approach}

\subsection{Data collection}

To pick a sample of the younger generation from the Hungarian society of 10 million people, we administered a questionnaire survey to university and college students. The surveys were made in Hungary between 2017 and 2018 in the 12 largest campuses, having selected nearly 16 thousand students. Sample representativeness is shown in the figure of 174,338 fulltime students in the sample (according to 2018 data), representing 86.2 per cent of the total of 202,300 students in Hungary. The survey also represented the young adult population with higher education qualifications, who - according to Paylab salary research platform data for Hungary - may become high-income earners in the future.

The questionnaire was made available for students via internal customised university platforms. The first section of the questionnaire relates to the respondent's gender, age, residential address and housing situation, work experience, and his or her parents' (foster parents') education, to map the demographic characteristics of this population. Next, questions were asked about their finances (propensity to save, spending habits and financial literacy), and about their perception of their financial awareness. The results of the respondents' selfassessment regarding financial literacy were then compared to their electronic banking habits 
(i.e. the usage of mobile and internet as a primary channel for banking) to test them (see e.g. Ackerman \& Wolman, 2007, Rai \& Sharma, 2019). The questions were worded according to the OECD methodology (OECD-INFE, 2018), with derogations due to the peculiarities of student respondents. The list of questions is the following:

- Have you got any savings? (What is the source of your savings? Scholarship, student work, or financial assistance from your parents?)

- What kinds of cash saving practices do you know from your family?

- Are you familiar with banks' savings products?

- Have you got a student loan? What chances do you see for repaying your student loan? How high deadweight effect will it have on you after your graduation?

- Do you currently keep a budget? If you start a family, would you use this opportunity? Can you see any significance in this during responsible family management?

- Are you familiar with the home financing loans that can be requested for starting a family? (How familiar are you with the economic nature of loans?)

- How beneficial do you think easy credits are? Have you got a personal loan? Do you plan to use one later on?

- Are you familiar with the governmental housing subsidy that can be requested in the framework of the government's pro-birth policy?

- Have you ever heard of the direct trigger of the global crisis that started in 2007-2008? Have you ever heard of overlending?

- What do you think of your financial literacy? Do you want to know more about finances? Whom do you expect to learn such things from?

- Do you consider the non-profit organisations established by commercial banks for improving financial literacy trustworthy?

- Are you familiar with the foundations established by the National Bank of Hungary for improving financial literacy and do you consider them trustworthy?

- Have you heard of civil society non-profit organisations established for improving financial literacy?

- Do you plan to give to charity in the future, and if yes, for what purposes? Do you think philanthropy improves social welfare? In your opinion, what charitable purposes may serve as bases for setting up private foundations? Do you think of granting to completely civil society organisations for the advancement of financial literacy? friends?

- Do you know of any charitable private foundations in your family or among your

- Do you prefer to donate to private or to institutional foundations supported by commercial banks?

- Do you know anything about the National Bank of Hungary's financial literacy improvement activities and do you consider its awareness-raising performed through foundations efficient?

- On a scale of 5, rate the activities performed in the interest of social welfare by nongovernment organisations aiming at improving financial literacy. On the same scale, how do your rate civil society organisations working to improve financial literacy but backed by financial institutions or by the central bank?

Note that the purpose of the research was not to provide a quantitative survey of the financial awareness of the university students (complete control tests). Numerous research findings have been published on this matter; see for example Beal \& Delpachitra, 2003, Chen \& Volpe, 1998, Shambare \& Rugimbana, 2012, Cull \& Whitton, 2011. Similarly, the aim was not to evaluate the educational systems of universities and the efficiency of transferring financial information (Fox et al., 2005; Hanna et al., 2010; Mandell \& Klein, 2009). This is 
because the improvement in the system of educational institutions would be sufficient in light of a quantitative survey of financial literacy; however, improvement in financial literacy requires a different attitude and also different institutional forms (Hastings et al., 2013). Rather, our research aim was to examine whether there is room for improving financial literacy in Hungary with the involvement of financial and non-profit organisations targeting the students in university education.

\subsection{Data analysis}

The overall picture that emerges from the responses obtained during the questionnaire survey of Hungarian university students suggests that young adults' propensity to save (for at least one year) is low, while they retain a high amount of cash. In our sample, on average 1 out of 5 responders deposits money on savings accounts. No more than approximately one-third of them use household budget calculators. The high ( 28 per cent) ratio of young adults with rapid credit facilities (personal loans) is a disquieting indication. Our findings are partly explained by the characteristic feature of Hungarian households that real purchasing power remains constant against rising propensity to borrow and increasing indebtedness (Huszti, 2018).

Based on their responses, nearly 70 per cent of the interviewed young people had hardly any understanding of the deeper causes that triggered the 2008 global economic crises, or not at all, and are not aware of the risks of excessive indebtedness. More than 75 per cent of the respondents consider the opportunities offered in the family incentives of the current Hungarian economic policy useful, and in accord with the general credit flow trends in Hungary, this forecasts indebtedness by young people who are about to start families in the near future. (Note: After the financial and lending crisis, mainly as a result of fiscal incentives to support families, starting from 2015, the appetite for loans began to pick up again in Hungary, as the family housing benefit and support for mortgage loans considerably boosted demand for housing loans, Sági \& Lentner, 2018).

The majority, approx. 82 per cent of the interviewed young adults would like to increase their practical skills in finances. On a scale of 1 to 5 , more than 90 per cent of the respondents confirmed the necessity of institutions undertaking to improve financial literacy, especially those financed by the central bank or by non-government organisations. 37.9 per cent of them consider non-profit organisations backed by the central bank and their efforts at complementing school educational to improve financial literacy as important or highly important; 78.9 per cent think that non-government organisations could have a really important role in financial literacy; and only 9.7 per cent relate improvement in financial literacy clearly to organisations supported by financial institutions (commercial banks). Of all the non-profit organisations in Hungary, respondents giving positive answers mentioned the OTP Fáy András Foundation, the Pénziránytü Alapítvány [Money Compass Foundation] established by the National Bank of Hungary, the Hungarian Banking Association and the Student Loan Centre, and the MNB's Pallas Athene foundations as good examples. Simultaneously, they expressed their opinion that there are no organisations other than the listed NGO's, which are supported by financial institutions or by the central bank, or if there are, then the organisations fully established by the civil society are invisible, although they would trust them more than commercial banks' organisations.

The survey also covered the charity aspect of financial literacy, not relating to direct financial interests. Many kinds of different intentions may underlie charity; however, we wanted to know whether or not the respondents thought that donation created community value. The young adults' responses have confirmed our assumption that they consider charity exemplary for the society and they themselves know patrons in their immediate families and 
among their friends. The majority of the respondents think that the foundations in the hands of rich private persons and non-profit organisations are capable of returning value to the society for the areas they finance (culture, financial literacy etc.).

\section{Conducting research and results}

In relation to our hypothesis, a five-level Likert scale was used to measure university students' confidence (trust) in NGOs, central bank's non-profit organisations, and financial institutions' non-profit organisations acting in their role in improving financial literacy. In order to analyse their attitudes, the responders (nearly sixteen thousand students) were characterised according to gender, educational field, and working experience, as well as the region's development level of the responders' residence, and their parents' educational level. In the questionnaire we detected how the responders evaluated their financial literacy, and that how predominantly they are using e-banking services (by a similar 1-5 scale). From their responses, we examined whether certain types of behavioural patterns could be detected via identifying clusters, using Ward method and ANOVA test.

\subsection{Application of Ward's method (test: ANOVA)}

The authors divided the respondent young adult (university student) population into groups according to the shared features in order to analyse the behavioural patterns, in the context of demographic backgrounds (gender, residence, and parents' educational level), university major, work experience and financial literacy of the individual groups. Using Ward's method (Ward 1963) for this purpose, six clusters were identified and set up in a 5-step agglomeration (Graph 1, Annex 1.).

The variance analysis (ANOVA test) showed significant differences between the clusters (Table 1). In exploratory data analysis, an ANOVA employs an additive data decomposition that provide a rationale for clusters. Since it is a form of statistical hypothesis testing used in the analysis of experimental data, its hypothesis is approved or rejected in case its test result is statistically significant by given parameters. The null hypothesis is that there is no difference between the means, the groups are the same for the mean of the target variable across the whole sample. The null hypothesis shall be rejected below the significance level of 0.05. Concerning our sample, the examined grouping variable has a significant effect on the dependent variable, i.e. the group averages differ (the null hypothesis has been rejected).

Table 1. ANOVA test

\begin{tabular}{lrrrrr}
\hline \multicolumn{7}{c}{ ANOVA } \\
\hline flitscore & \multicolumn{1}{c}{} & \\
\hline \multicolumn{7}{l}{ Sum of Squares } & df & MeanSquare & F & Sig. \\
\hline BetweenGroups & 5258,323 & 4 & 1314,581 & 937,536 & 0 \\
\hline WithinGroups & 21992,974 & 15685 & 1,402 & & \\
\hline Total & 27251,297 & 15689 & & & \\
\hline
\end{tabular}

Source: own from SPSS 


\subsection{Description of the clusters}

Based on their characteristic features, the clusters may be described as follows:

1. Ambitions women

Cluster 1 typically includes women (by 80\%) who study economics and for the most part work while studying. Their homes are located in moderately developed or occasionally underdeveloped regions, and their parents have, for the most part, secondary school or lower qualifications. Most (nearly $70 \%$ of) respondents consider their financial literacy good or excellent, and this is supported by the fact that a high ratio use electronic banking channels, considered one of the characteristic features of financial literacy.

2. Men from less well-off backgrounds

Cluster 2 includes nearly three times more men than women, and most of them study some kind of an economic subject. More detailed questions revealed that although most of them were not employed, they proactively contributed to their families' businesses (mostly run out of necessity). An outstandingly high number of these respondents (1029 out of 1149) live in underdeveloped regions, and their parents have secondary school qualifications, but no higher. they almost exclusively rate their own financial literacy as poor or moderate, and they use electronic banking more moderately than the full population.

3 . Young people studying subjects other than economics, mostly men

Cluster 3 includes more men than women (their proportions are $58 \%$ and $42 \%$, respectively), and most of them study technical or other (non-economic) subjects in higher education. More than half of them regularly work while studying. Their homes are located in moderately or highly developed regions. Their parents have various levels of education. More than 80 per cent of them rate their financial literacy as excellent, however, they only use electronic banking facilities moderately.

4. Young people studying subjects other than economics, mostly women

As Cluster 4 and Cluster 5 do not significantly differ, they have been merged. Similar to the previous cluster (Cluster 3), the majority (92.5\%) participate in technical or other (noneconomic) education. They regularly work during their studies. Their homes are located in moderately or highly developed regions. Their parents have higher qualifications. More than 70 per cent of them rated their financial literacy as weak to moderate, and the number of users of electronic banking channels is negligible.

5. Young people from well-off environments ("rich kids")

Finally, most participants in Cluster 6 are men (their proportion is above 80 per cent), study subjects other than economics, and do not work during their studies. Their homes are located in moderately or highly developed regions. The majority comes from highly qualified families. $86 \%$ rate their financial literacy as good or excellent, and this is slightly in conflict with the fact that they regularly use electronic banking facilities but not for all available financial operations.

The following tables show the clusters as they have been described in above, according to the responders' demographic data (Table 2), their self-evaluation of financial literacy and their banking habits (i.e. usage of e-banking services) (Table3). The respective figures refer to the number of responders among university students. 
Table 2. Crosstabs for gender, educational field, working, region's development and parents' educational level

\begin{tabular}{|c|c|c|c|c|c|c|c|c|}
\hline \multicolumn{9}{|c|}{ Crosstab } \\
\hline \multicolumn{9}{|c|}{ Count } \\
\hline & & \multicolumn{2}{|c|}{ gender } & \multirow[t]{2}{*}{ Total } & \multicolumn{3}{|c|}{ education field } & \multirow[t]{2}{*}{ Total } \\
\hline & & male & female & & economics & $\begin{array}{l}\text { engineering, } \\
\text { technology }\end{array}$ & other & \\
\hline \multirow{6}{*}{$\begin{array}{l}\text { Ward } \\
\text { Method }\end{array}$} & 1 & 473 & 1904 & 2377 & 2310 & 15 & 52 & 2377 \\
\hline & 2 & 853 & 296 & 1149 & 872 & 13 & 264 & 1149 \\
\hline & 3 & 1203 & 866 & 2069 & 13 & 1421 & 635 & 2069 \\
\hline & 4 & 204 & 4213 & 4417 & 433 & 1954 & 2030 & 4417 \\
\hline & 5 & 12 & 1706 & 1718 & 27 & 32 & 1659 & 1718 \\
\hline & 6 & 3319 & 641 & 3960 & 76 & 113 & 3771 & 3960 \\
\hline \multirow[t]{3}{*}{ Total } & & 6064 & 9626 & 15690 & 3731 & 3548 & 8411 & 15690 \\
\hline & & \multicolumn{2}{|c|}{ working } & Total & \multicolumn{3}{|c|}{ region's development } & \multirow[t]{2}{*}{ Total } \\
\hline & & no & yes & & $\begin{array}{c}\text { GDP per } \\
\text { capita } \\
\text { below } \\
75 \% \text { of } \\
\text { average }\end{array}$ & $\begin{array}{c}\text { GDP per } \\
\text { capita } \\
\text { between } \\
75 \%-100 \%\end{array}$ & $\begin{array}{c}\text { GDP per } \\
\text { capita } \\
\text { above100\% }\end{array}$ & \\
\hline \multirow{6}{*}{$\begin{array}{l}\text { Ward } \\
\text { Method }\end{array}$} & 1 & 586 & 1791 & 2377 & 611 & 1685 & 81 & 2377 \\
\hline & 2 & 845 & 304 & 1149 & 1029 & 107 & 13 & 1149 \\
\hline & 3 & 850 & 1219 & 2069 & 13 & 1020 & 1036 & 2069 \\
\hline & 4 & 682 & 3735 & 4417 & 530 & 1632 & 2255 & 4417 \\
\hline & 5 & 432 & 1286 & 1718 & 11 & 272 & 1435 & 1718 \\
\hline & 6 & 3487 & 473 & 3960 & 47 & 2272 & 1641 & 3960 \\
\hline \multirow[t]{3}{*}{ Total } & & 6882 & 8808 & 15690 & 2241 & 6988 & 6461 & 15690 \\
\hline & & \multicolumn{6}{|c|}{ parents' educational level } & \multirow[t]{2}{*}{ Total } \\
\hline & & $\begin{array}{l}\text { primary- } \\
\text { primary }\end{array}$ & $\begin{array}{c}\text { primary- } \\
\text { secondary }\end{array}$ & $\begin{array}{l}\text { primary- } \\
\text { higher }\end{array}$ & $\begin{array}{l}\text { secondary- } \\
\text { secondary }\end{array}$ & $\begin{array}{c}\text { secondary- } \\
\text { higher }\end{array}$ & $\begin{array}{l}\text { higher- } \\
\text { higher }\end{array}$ & \\
\hline \multirow{6}{*}{$\begin{array}{l}\text { Ward } \\
\text { Method }\end{array}$} & 1 & 317 & 248 & 457 & 1272 & 75 & 8 & 2377 \\
\hline & 2 & 135 & 349 & 155 & 471 & 15 & 24 & 1149 \\
\hline & 3 & 388 & 301 & 132 & 806 & 343 & 99 & 2069 \\
\hline & 4 & 37 & 47 & 8 & 1154 & 2599 & 572 & 4417 \\
\hline & 5 & 19 & 43 & 5 & 22 & 1301 & 328 & 1718 \\
\hline & 6 & 9 & 84 & 21 & 213 & 1114 & 2519 & 3960 \\
\hline Total & & 905 & 1072 & 778 & 3938 & 5447 & 3550 & 15690 \\
\hline
\end{tabular}

Source: own from SPSS 
Table 3. Crosstabs for self-evaluation of financial literacy, and e-banking

\begin{tabular}{|c|c|c|c|c|c|c|c|}
\hline \multicolumn{8}{|l|}{ Crosstab } \\
\hline \multicolumn{8}{|l|}{ Count } \\
\hline & & \multicolumn{5}{|c|}{ self-evaluation of financial literacy } & \multirow[t]{2}{*}{ Total } \\
\hline & & 1 & 2 & 3 & 4 & 5 & \\
\hline \multirow[t]{6}{*}{ Ward Method } & 1 & 345 & 56 & 341 & 859 & 776 & 2377 \\
\hline & 2 & 792 & 0 & 352 & 5 & 0 & 1149 \\
\hline & 3 & 13 & 228 & 64 & 76 & 1688 & 2069 \\
\hline & 4 & 1253 & 622 & 1187 & 1310 & 45 & 4417 \\
\hline & 5 & 23 & 11 & 1242 & 439 & 3 & 1718 \\
\hline & 6 & 3 & 40 & 503 & 386 & 3028 & 3960 \\
\hline \multirow[t]{3}{*}{ Total } & & 2429 & 957 & 3689 & 3075 & 5540 & 15690 \\
\hline & & \multicolumn{5}{|c|}{ ebank } & \multirow[t]{2}{*}{ Total } \\
\hline & & 1 & 2 & 3 & 4 & 5 & \\
\hline \multirow[t]{6}{*}{ Ward Method } & 1 & 0 & 0 & 98 & 519 & 1760 & 2377 \\
\hline & 2 & 53 & 251 & 645 & 45 & 155 & 1149 \\
\hline & 3 & 663 & 734 & 349 & 6 & 317 & 2069 \\
\hline & 4 & 2159 & 718 & 1476 & 25 & 39 & 4417 \\
\hline & 5 & 2 & 0 & 94 & 948 & 674 & 1718 \\
\hline & 6 & 56 & 789 & 1994 & 616 & 505 & 3960 \\
\hline Total & & 2933 & 2492 & 4656 & 2159 & 3450 & 15690 \\
\hline
\end{tabular}

Source: own from SPSS

We examined what institutional solution the above groups would expect to improve financial literacy: whether it was educational institutions, civil society organisations or government organisations. The findings show that the more ambitious students, studying economics, characteristically consider the role undertaken by educational institutions collaborating with the foundations of the National Bank of Hungary and by civil society organisations as good examples. Nevertheless, they think the future of the authentic dissemination of financial information lies with privately established civil society organisations, and they are willing to donate for such a goal once they become an independent earners. The majority of the respondents are, however, uncertain or refuse the role of foundations established by commercial banks. The only exception to this rule are those who come from less developed regions, who consider the presence of bigger banks necessary also in the field of financial literacy (Table 4). 
Table 4. Trust in NGOs / central bank's non-profit organisations/financial institutions' nonprofit organisations in improving financial literacy (The respective figures show how strongly the responders put their trust in NGOs / central bank's non-profit organisations / financial institutions' non-profit organisations in improving financial literacy, measured by a Likert scale.)

\begin{tabular}{|c|c|c|c|c|c|c|c|}
\hline \multicolumn{8}{|l|}{ Crosstab } \\
\hline \multicolumn{8}{|l|}{ Count } \\
\hline & & \multicolumn{5}{|c|}{ NGOs } & \multirow[t]{2}{*}{ Total } \\
\hline & & 1 & 2 & 3 & 4 & 5 & \\
\hline \multirow[t]{6}{*}{ Ward Method } & 1 & 18 & 65 & 4 & 2011 & 279 & 2377 \\
\hline & 2 & 23 & 32 & 17 & 296 & 781 & 1149 \\
\hline & 3 & 10 & 49 & 3 & 1943 & 64 & 2069 \\
\hline & 4 & 165 & 35 & 1562 & 2257 & 398 & 4417 \\
\hline & 5 & 126 & 614 & 390 & 127 & 461 & 1718 \\
\hline & 6 & 87 & 13 & 99 & 2314 & 1447 & 3960 \\
\hline \multirow[t]{3}{*}{ Total } & & 429 & 808 & 2075 & 8948 & 3430 & 15690 \\
\hline & & \multicolumn{5}{|c|}{ central bank's non-profit organisations } & \multirow[t]{2}{*}{ Total } \\
\hline & & 1 & 2 & 3 & 4 & 5 & \\
\hline \multirow[t]{6}{*}{ Ward Method } & 1 & 109 & 101 & 635 & 157 & 1375 & 2377 \\
\hline & 2 & 83 & 31 & 4 & 768 & 263 & 1149 \\
\hline & 3 & 128 & 773 & 1066 & 14 & 88 & 2069 \\
\hline & 4 & 37 & 148 & 4013 & 15 & 204 & 4417 \\
\hline & 5 & 40 & 1 & 1417 & 167 & 93 & 1718 \\
\hline & 6 & 10 & 69 & 1085 & 1346 & 1450 & 3960 \\
\hline \multirow[t]{3}{*}{ Total } & & 407 & 1123 & 8220 & 2467 & 3473 & 15690 \\
\hline & & \multicolumn{5}{|c|}{$\begin{array}{l}\text { financial institutions' non-profit } \\
\text { organisations }\end{array}$} & \multirow[t]{2}{*}{ Total } \\
\hline & & 1 & 2 & 3 & 4 & 5 & \\
\hline \multirow[t]{6}{*}{ Ward Method } & 1 & 327 & 1872 & 78 & 54 & 46 & 2377 \\
\hline & 2 & 3 & 543 & 55 & 505 & 43 & 1149 \\
\hline & 3 & 14 & 1911 & 15 & 42 & 87 & 2069 \\
\hline & 4 & 224 & 2829 & 801 & 392 & 171 & 4417 \\
\hline & 5 & 111 & 1391 & 127 & 31 & 58 & 1718 \\
\hline & 6 & 79 & 3260 & 521 & 34 & 66 & 3960 \\
\hline Total & & 758 & 11806 & 1597 & 1058 & 471 & 15690 \\
\hline
\end{tabular}

Source: own from SPSS

Note that the high refusal rate of commercial banks is presumably due to the high ratio of subprime household loans, amounting to 28 per cent of GDP, and disbursed between 2004 and 2008 and settled in foreign exchange, and to the drastic exchange rate deterioration caused by the crisis (Bodzási, 2019). Due to insolvency, nearly 25 per cent of the total population of Hungary was (directly or indirectly) affected, litigations and legal disputes between the population and banks became endemic, and this is deeply set in the memories of the population. A more thorough analysis of this matter requires further research. 


\section{Conclusion}

In this study, financial literacy is analysed through the example of a country located in the post-socialist region, which has different socialisation, financial literacy and debt behaviour trajectories than Anglo-Saxon countries (Cwynaret al., 2019). Based on a representative sample of students, the findings concerning the financial literacy and the attitudes of the respondents forecast the social challenges to be faced in the future in this small country, which is still considered as an emerging market economy, due to the late rise of the middle class. In Hungary, the voluntarily organised non-government organisations proven by this research to be indispensable in improving financial literacy are extremely rare. In the case of non-profit institutions established by private capitalists as a result of an organic capital accumulation, the founder's business interest and the desired social goal that provides a basis for the organisation's operation are de facto separate. By contrast, in the case of the foundations of commercial banks, the respondents typically rated the social consideration that served the improvement of financial literacy as secondary. As for the latter, the respondents strongly presumed the bank's concealed marketing considerations and criticised that financial institutions reinvested only a small fragment of their profit into the society. The respondents consider the National Bank of Hungary's efforts at improving financial literacy considerably more trustworthy and beneficial to society.

In addition, the findings of the survey confirm that in improving financial literacy, educational institutions have the primary role (Swieckaet al., 2020), as the non-profit organisations established by commercial banks, by the central bank or by civil society stakeholders, which are at the heart of this study, may have a secondary (complementary) role in raising financial awareness. In our opinion, teaching finance should start primarily in the family and at school. Note, however, that the students of economic (and technological) higher educational institutions perform at a significantly higher level than those at other institutions. The respondents' financial literacy is further explained by the family background, the level of development in their home regions and the students' work experience. Foundations established by banks and the central bank are involved in the dissemination of financial information; and by undertaking multiple tasks, they promote the spread of practical financial skills and of financial and banking innovations. However, there are NGO's established by private person founders, and as the respondents clearly associate the aim of improving social welfare with such organisations, they do not have any entity they could trust for financial and charity purposes.

Due to poorly developed financial literacy, the central bank and its foundations focusing their activities on financial literacy have a key role, as also confirmed by the respondents. The research findings prove that commercial banks' foundations are considerably less efficient in reaching social stakeholders, primarily due to the lack of confidence in them. Our paper highlights that the civil society is able to provide sustainable funding to the institutionalised concept of raising financial awareness and improving financial literacy among young adults, independent of state budgets and central bank funding. Civil society organisations could be instrumental in reaching the younger generation endeavouring to acquire financial literacy, as young people have confidence in them for advice in the management of their finances (and they have less confidence in institutions meant to improve financial literacy with a commercial banking background). 


\section{References}

Ackerman, P. L., \& Wolman, S. D. (2007). Determinants and validity of self-estimates of abilities and self-concept measures. Journal of Experimental Psychology: Applied, 13(2), 57-78. https://doi.org/10.1037/1076-898X.13.2.57

Agarwal, S., Amromin, G., Ben-David, I., Chomsisengphet, S., \& Evanoff, D. D. (2014). Predatory lending and the subprime crisis. Journal of Financial Economics, 113(1), 2952. https://doi.org/10.1016/j.jfineco.2014.02.008

Ameriks, J., Caplin, A., \& Leahy, J. (2003). Wealth accumulation and propensity to plan. Quarterly Journal of Economics, 118(3), 1007-1047. https://doi.org/10.1162/00335530360698487

Atkinson, A., \& Messy, F. (2013). Promoting Financial Inclusion through Financial Education: OECD/INFE Evidence, Policies and Practice. OECD Working Papers on Finance, Insurance and Private Pensions, No. 34, OECD Publishing, Paris, https://doi.org/10.1787/5k3xz6m88smp-en

Bateman, Z., Eckert, C., Geweke, J., Louviere, J., Thorp, S., \& Satchell, S. (2011). Financial Competence and Expectations Formation: Evidence from Australia. Economic Record, 88(280), 39-63.

Bazley, W. J., Bonaparte, Y., \& Korniotis, G. M. (2020). Financial Self-awareness: Who Knows What They Don't Know? Finance Research Letters; No. 101445. http://dx.doi.org/10.1016/j.frl.2020.101445

Beal, D. J., \& Delpachitra, S. B. (2003). Financial literacy among Australian university students. Economic Papers, 22(1), 65-78. https://doi.org/10.1111/j.1759$\underline{\text { 3441.2003.tb00337.x }}$

Berková, K., \& Krpálek, P. (2017). Approaches to the development of cognitive process dimensions in financial literacy: an empirical study. Journal of International Studies, 10(3), 173-188. doi:10.14254/2071-8330.2017/10-3/13

Bilan, Y., Mishchuk, H., Samoliuk, N., \& Yurchyk, H. (2020). Impact of Income Distribution on Social and Economic Well-Being of the State. Sustainability, 12(1), 429. doi:10.3390/su12010429

Bodzási, B. (2019). Legislative steps in Hungary to address issues connected with foreign currency-based consumer loans. In B. Bodzási (Eds.) Foreign currency lending in Hungary: A legal and economic analysis of foreign currency lending. Budapest: Corvinus University of Budapest, 55-89.

Calcagno, R., \& Monticone, C. (2015). Financial literacy and the demand for financial advice. Journal of Banking \& Finance, 50, 363-380. https://doi.org/10.1016/j.jbankfin.2014.03.013

Chen, H., \& Volpe, R. P. (1998). An analysis of personal financial literacy among college students. Financial Services Review, 7(2), 107-128, https://doi.org/10.1016/S10570810(99)80006-7

Clark, R., d'Ambrosio, M., McDermed, A., \& Sawant, K. (2006). Retirement Plans and Saving Decisions: The Role of Information and Education. Journal of Pension Economics and Finance, 5(1), 45-67.

Courchane, M., \& Zorn, P. (2008) Consumer Credit Literacy: What Price Perception. Journal of Economics and Business, 60, 125-138.

Croy, G., Gerrans, P., \& Speelman, C. (2010). The Role and Relevance of Domain Knowledge, Perceptions of Planning Importance, and Risk Tolerance in Predicting Savings Intentions. Journal of Economic Psychology, 31(6), 860-871. 
Cull, M., \& Whitton, D. (2011). University Students' Financial Literacy Levels: Obstacles and Aids. The Economic and Labour Relations Review, 22(1), 99-114. https://doi.org/10.1177/103530461102200106

Cwynar, A., Cwynar, W., Baryla-Matejczuk, M., \& Betancort, M. (2019). Sustainable Debt Behaviour and Well-Being of Young Adults: The Role of Parental Financial Socialisation Process. Sustainability, 11(24), 7210. https://doi.org/10.3390/su11247210

Csaba, L. (2019). Unorthodoxy in Hungary: an Illiberal Success Story? Post-Communist Economies Paper, 14, https://doi.org/10.1080/14631377.2019.1641949

Dahlstrom, R. N. (2014). How to recover trust in the banking industry? A game theory approach to empirical analyses of bank and corporate customer relationships. International Journal of Bank Marketing, 32(4), 268-278. https://doi.org/10.1108/IJBM-03-2014-0042

Dhandayuthapani, S. P., \& Vinothkumar, N. (2020). Financial Literacy and its Determinants. International Journal for Research in Applied Science \& Engineering Technology, 8 (VII), 1174-1179. https://doi.org/10.22214/ijraset.2020.30445

Dobák, P., \& Sági, J. (2005). Fogyasztási hitelek: növekvő eladósodottság? (Retail loans: increasing indebtedness?) Hitelintézeti Szemle/ Financial and Economic Review, 4(1), 127.

Falk, A., Becker, A., Dohmen, T., Enke, B., Huffman, D., \& Sunde, U. (2018). Global Evidence on Economic Preferences. The Quarterly Journal of Economics, 133(4), 1645-1692. https://doi.org/10.1093/qje/qjy013

Fernandes, D., Lynch, J. G., \& Netemeyer, R. (2014). Financial Literacy, Financial Education, and Downstream Financial Behaviors. Management Science, 60(8), 1861-1883. https://doi.org/10.1287/mnsc.2013.1849

Fox, J., Bartholomae, S., \& Lee, J. (2005). Building the case for financial education. Journal of Consumer Affairs, 39, 195-214. https://doi.org/10.1111/j.1745-6606.2005.00009.x

Galperti, S.A. (2017). Theory of Personal Budgeting. SSRN Electronic Journal, 58. https://doi.org/10.2139/ssrn.2964067

Guerrieri, V., \& Lorenzoni, G. (2017). Credit Crises, Precautionary Savings, and the Liquidity Trap. The Quarterly Journal of Economics, 132(3), 1427-1467, https://doi.org/10.1093/qje/qjx005

Hanna, M. E., Hill, R. R., \& Perdue, G. (2010). School of study and financial literacy. Journal of Economics and Economic Education Research, 11(3), 29-37.

Hansen, T. (2012). Understanding Trust in Financial Services: The Influence of Financial Healthiness, Knowledge, and Satisfaction. Journal of Service Research, 15, 280-295. https://doi.org/10.1177/1094670512439105

Hastings, J. S., Madrian, B. C., \& Skimmyhorn, W. L. (2013). Financial Literacy, Financial Education, and Economic Outcomes. AnnualReview of Economics, 5, 347-373. https://doi.org/10.1146/annurev-economics-082312-125807

Haynes-Bordas, R., Kiss, D. E., \& Yilmazer, T. (2008). Effectiveness of Financial Education on Financial Management Behavior and Account Usage: Evidence from a 'Second Chance' Program. Journal of Family and Economic Issues, 29(3), 362-390.

Hogarth, J. (2006). Financial education and economic development. Paper presented at Improving Financial Literacy: International Conference Hosted by the Russian G8 Presidency in Cooperation with the OECD. Available online: http://www. oecd.org/dataoecd/20/50/37742200.pdf (accessed on 19 Jan 2020).

Huszti, E. (2018). Tetrahedron Effect. Public Finance Quarterly, 4, 433-447. Available online: https://www.penzugyiszemle.hu/pfa/public-finance-quarterly-archivearticles/tetrahedron-effect (accessed on 19 Jan 2020). 
Kaiser, T., \& Menkhoff, L. (2017). Does Financial Education Impact Financial Literacy and Financial Behavior, and If So, When? World Bank Policy Research Working Paper, No. 8161, 1-77.https://doi.org/10.1596/1813-9450-8161

Kato, S., Ashley, S.R., \& Weaver, R.L. (2018). Insights for Measuring Social Value: Classification of Measures Related to the Capabilities Approach. Voluntas: International Journal of Voluntary and Nonprofit Organizations, 29, 558. https://doi.org/10.1007/s11266-017-9912-7

Kempson, E. (2009). Framework for the Development of Financial Literacy Baseline Surveys: A First International Comparative Analysis, OECD Working Papers on Finance, Insurance and Private Pensions, 1, 31. OECD Publishing. https://doi.org/10.1787/5kmddpz7m9zq-en

Kovács, L., \& Terták, E. (2019). Financial Literacy. Theory and Evidence. Bratislava: Verlag Dashöfer, Vydavatelstvo Publishing, 150.

Lentner, Cs. (2020). East of Europe, West of Asia. L'Harmattan Publishing, Paris, 304.

Lentner, Cs., Szegedi, K., \& Tatay, T. (2015). Corporate Social Responsibility in the Banking Sector. Public Finance Quarterly, 60(1), 95-103.

Lusardi, A., Mitchell, O. S., \& Curto, V. (2010). Financial Literacy among the Young. Journal of Consumer Affairs, 44, 358-380. https://doi.org/10.1111/j.1745-6606.2010.01173.x

Lusardi, A., \& Tufano, P. (2015). Debt literacy, financial experiences, and over indebtedness. Journal of Pension Economics and Finance, 14(04), 332-368. https://doi.org/10.1017/s1474747215000232

Lynch J. G., Netemeyer, R., Spiller, S. A., \& Zammit, A. (2010). A generalizable scale of propensity to plan: The long and the short of planning for time and money. J. Consumer Res., 37(June), 108-128. https://doi.org/10.1086/649907

Maas, K., \& Liket, K. (2011). Social impact measurement: Classification of methods. In R. Burritt, S. Schaltegger, M. Bennett, T. Pohjola, \& M. Csutora (Eds.), Environmental Management Accounting and Supply Chain Management, 27, Dordrecht: Springer, 171202.

Madaras, A., \& Varga, J. (2014). Changes in Education Funding in Hungary. Acta Universitatis Sapientuae Economics and Business, 2, 59-74. https://doi.org/10.2478/auseb-2014-0010

Maier, F., Schober, C., Simsa, R., \& Millner, R. (2015). SROI as a Method for Evaluation Research: Understanding Merits and Limitations. Voluntas: International Journal of Voluntary and Nonprofit Organizations, 26(5), 1805-1830. https://doi.org/10.1007/s11266-014-9490-x

Mandell, L., \& Schmid Klein, L. (2009). The Impact of Financial Literacy Education on Subsequent Financial Behavior. Journal of Financial Counseling and Planning, 20(1), $15-24$.

Marcolin, S., \& Abraham, A. (2006). Financial literacy research: current literature and future opportunities, 11. In P. Basu, G. O'Neill \& A. Travaglione (Eds.), Proceedings of the 3rd International Conference on Contemporary Business, Leura NSW, Australia: Faculty of Commerce, Charles Stuart University

Matolcsy, Gy. (2016). Economic balance and growth. Kairosz Publishing, Budapest. 680.

McCormick, M. H. (2009). The Effectiveness of Youth Financial Education: A Review of the Literature. Journal of Financial Counseling and Planning, 20(1), 70-83.

Mihályi, P., \& Szelényi, I. (2019). The Place of Rent-Seeking and Corruption in Varieties of Capitalism Models. In T. Gerőcs, and M. Szanyi (eds.), Market Liberalism and Economic Patriotism in the Capitalist World-System, Cham: PalgraveMacmillan, 5, 67-97. 
Mitchell, O. S., \& Lusardi, A. (2015). Financial Literacy and Economic Outcomes: Evidence and Policy Implications. SSRN Electronic Journal, 01, 1-15. https://doi.org/10.2139/ssrn.2568732

Németh, E., \& Zsótér, B. (2019). Anxious spenders: Background factors of financial vulnerability. Economics and Sociology, 12(2), 147-169. doi:10.14254/2071789X.2019/12-2/9

OECD-INFE (2016). International Survey of Adult Financial Literacy Competencies. OECD, Paris. Available online: www.oecd.org/finance/OECD-INFE-International-Survey-ofAdult-Financial-Literacy-Competencies.pdf (accessed on 19 Jan 2020).

OECD-INFE (2018). Toolkit for Measuring Financial Literacy and Financial Inclusion, OECD, Paris. Available online: https://www.oecd.org/finance/financial-education/2018-INFEFinLit-Measurement-Toolkit.pdf (accessed on 19 Jan 2020).

Potrich, A., Vieira, K., \& Mendes-Da-Silva, W. (2016). Development of a financial literacy model for university students. Management Research Review, 39(3), 356-376. https://doi.org/10.1108/MRR-06-2014-0143

Qizilbash, M. (2002). Development, common foes and shared values. Review of Political Economy, 14(4), 463-480. https://doi.org/10.1080/0953825022000009906

Quach, H. (2016). Does access to finance improve household welfare? Investment Management and Financial Innovations, 13(2), 76-86. https://doi.org/10.21511/imfi.13(2).2016.08

Rai, K., \& Sharma, M. (2019). A Study on Awareness about Digital Financial Services among Students. SSRN Electronic Journal; 600-607. http://dx.doi.org/10.2139/ssrn.3308732

Remund, D.L. (2010). Financial literacy explicated: The case for a clearer definition in an increasingly complex economy. J. Consum. Aff. 44, 276-295. https://doi.org/10.1111/j.1745-6606.2010.01169.x

Rikmann, E., \& Keedus, L. (2012). Civic Sectors in Transformation and Beyond: Preliminaries for a Comparison of Six Central and Eastern European Societies. Voluntas: International Journal of Voluntary and Nonprofit Organizations, 24(1), 149-166. https://doi.org/10.1007/s11266-012-9305-x

Rim, H., Yang, S., \& Lee, J. (2016). Strategic partnerships with nonprofits in corporate social responsibility (CSR): The mediating role of perceived altruism and organizational identification. Journal of Business Research, 69(9), 3213-3219, https://doi.org/10.1016/j.jbusres.2016.02.035

Robeyns, I. (2006). The capability approach in practice. Journal of Political Philosophy, 14(3), 351-376.

Sági, J., \& Lentner, Cs. (2018). Certain Aspects of Family Policy Incentives for Childbearing - A Hungarian Study with an International Outlook. Sustainability, 10(11), 3976. https://doi.org/10.3390/su10113976

Sági, J., \& Lentner, Cs. (2019). Post-crisis trends in household credit market behavior: evidence from Hungary (Literature review). Banks and Bank Systems, 14(3), 162-174. https://doi.org/10.21511/bbs.14(3).2019.14

Sen, A. (2004). Capabilities, lists, and public reason: Continuing the conversation. Feminist Economics, 10, 77-80.

Shambare, R., \& Rugimbana, R. (2012). Financial literacy among the educated: An exploratory study of selected university students in South Africa. Thunderbird Int'l Bus Rev, 54, 581590. https://doi.org/10.1002/tie.21485

Spolaore, E., \& Wacziarg, R. (2013). How Deep Are the Roots of Economic Development? Journal of Economic Literature, 51, 325-369. https://doi.org/10.1257/jel.51.2.325 
Stroschein, S. (2002). NGO Strategies for Hungarian and Roma Minorities in Central Europe. Voluntas: International Journal of Voluntary and Nonprofit Organizations, 13(1), 1-26. https://doi.org/10.1023/A:101479371

Swiecka, B., Yeşildağ, E., Özen, E., \& Grima, S. (2020). Financial literacy: the case of Poland. Sustainability, 12(2), 700. https://doi.org/10.3390/su12020700

Van Rooij, M., Lusardi, A., \& Alessie, R. (2011). Financial literacy and stock market participation. Journal of Financial Economics, 101(2), 449-472.

Walker, M. (2005). Amartya Sen's capability approach and education, Educational Action Research, 13(1), 103-110. https://doi.org/10.1080/09650790500200279

Ward, J. H. Jr. (1963). Hierarchical Grouping to Optimize an Objective Function. Journal of the American Statistical Association, 58, 236-244. 


\section{Annex 1}

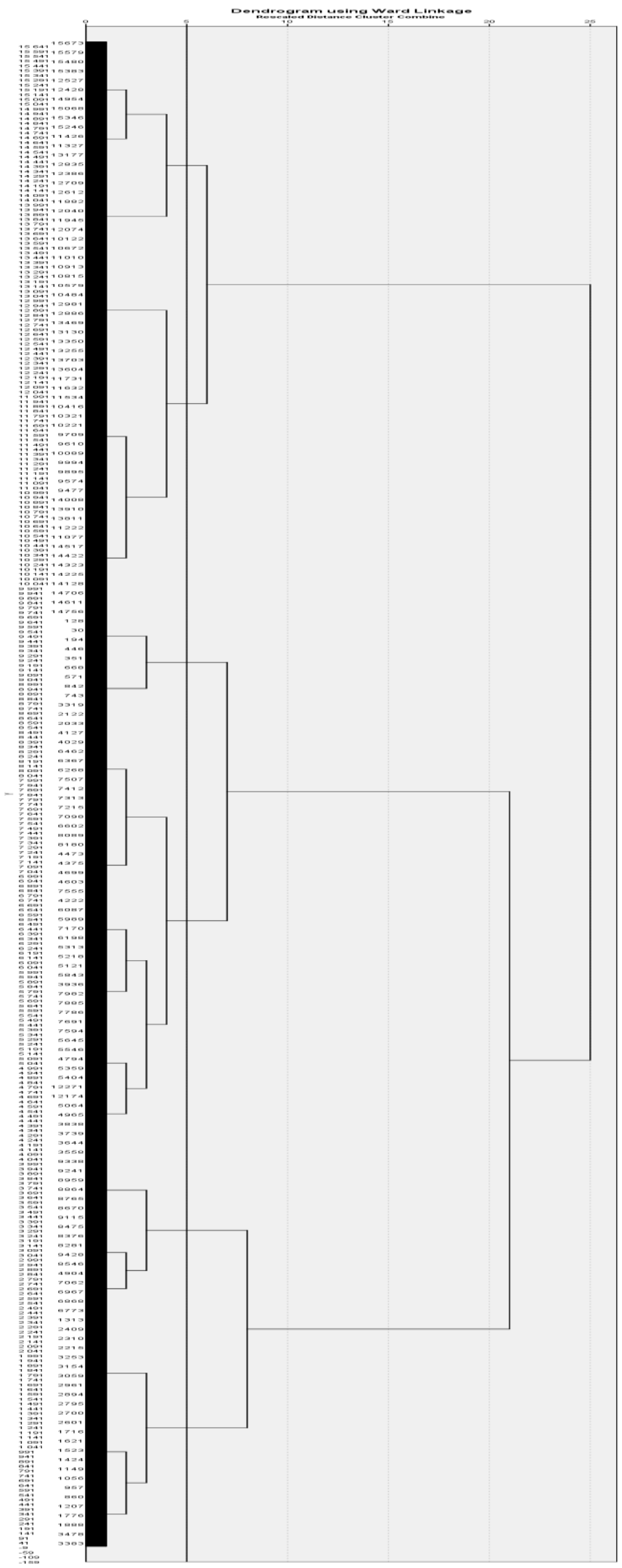

Graph 1. Dendogram using Ward linkage

Source: own from SPSS 